\title{
O encontro com a capoeira no tempo da vadiação
}

\author{
Flávio Soares Alves*
}

\begin{abstract}
Resumo: O artigo é parte de uma tese de doutorado que investigou às práticas de constituição/invenção do capoeirista. Acompanhamos grupos de capoeira Angola e Regional em São Paulo, Piracicaba, Botucatu e Jaú. O princípio da cartografia (DELEUZE; GUATTARI, 1995a) mobilizou a investigação, permitindo a constituição dos diários e entrevistas, como movimentos produzidos entre pesquisador e sujeitos. A escritura da pesquisa serviu-se das relações e singularidades descobertas nestes movimentos para forjar o exercício analítico, compreendendo-o como multiplicidade. Observamos que em meio ao tempo da vadiação, a capoeira surge como movimento a partir do cultivo da ginga. Deste cultivo decorre o exercício do treino na capoeira Regional e o exercício da convivência na capoeira Angola. Tais práticas de cultivo, embora distintas, exigem certa disposição ao imprevisível, sem o qual não se instala a experiência do brincar - a vadiação tampouco o desejo do capoeirista de tomar a capoeira como prática de sua existência.
\end{abstract}

Palavras-chave: Capoeira. Aprendizagem. Arte de viver.

\section{INTRODUÇÃO}

Este artigo abre um campo de discussões sobre os movimentos que atravessam o momento de encontro do capoeirista com a capoeira ${ }^{1}$. Em meio a este encontro inscreve-se o tempo da vadiação, ou seja, o tempo no qual o capoeirista se envolve e é envolvido pela capoeira.

\footnotetext{
"Doutor em ciências pela Escola de Educação Física e Esporte da USP - SP; Mestre em Artes pelo Instituto de Artes da UNICAMP, São Paulo, SP, Brasil. E-mail: flavio_salves@hotmail.com ${ }^{1}$ Capoeirista é o praticante da capoeira. Segundo Falcão (2004), o termo "capoeira" pontua justamente, no âmbito da cultura, o agente da capoeira, enquanto o termo "capoeirista" sugere uma intervenção mais específica - típica do especialista. Os grupos de capoeira estudados neste trabalho utilizam tanto o termo "capoeira", quanto "capoeirista". Os termos se revezam com frequência. Para facilitar a regência do texto e evitar possíveis confusões na compreensão da escrita, optamos por assumir o termo "capoeirista".
} 
Como primeiro movimento imerso nesta outra termporalidade instalada pela vadiação, observou-se a experiência da ginga. Neste texto iremos nos ocupar com as diferentes práticas de cultivo desta ginga, para tanto, mapeamos seus movimentos na capoeira Regional - descobrindo aí o espaço do treino - e na capoeira Angola experimentando o exercício e o desafio da convivência. Para além das distinções de estilo, estivemos atentos à experiência do brincar como movimento transgressor que alimenta o desejo do capoeirista pela capoeira, ao colocá-lo face a atração instigante e intensiva do imprevisível.

Esta discussão faz parte de uma tese de doutorado que investigou as práticas através das quais o capoeirista toma para si a capoeira e faz desta apropriação uma prática de invenção de si mesmo $^{2}$.

O primeiro passo da pesquisa foi assumir um processo de rastreamento de grupos de capoeira Angola e capoeira Regional no estado de São Paulo. A busca por grupos de capoeira nos aproximou dos seguintes grupos: Grupo Capoeira Brasil, formado pelo contramestre Buda na cidade de Botucatu; Grupo Amukenguê, do mestre Marcial na cidade de Jaú; Grupo Projete Liberdade, de mestre Gladson e professor Vinícius, no Centro de Práticas Esportivas da USP, em São Paulo; Escola de Capoeira Raiz de Angola, de mestre Zequinha, da cidade de Piracicaba; Centro de Capoeira Angola Angoleiro Sim Sinhô, de mestre Plínio, no bairro de Perdizes, na cidade de São Paulo; Associação de Capoeira Angola Senhor do Bonfim, de mestre Ananias, no bairro Bela Vista, na cidade de São Paulo; Grupo Capoeira Ginga-Brasília, de mestre Brasília, na Vila Madalena.

A proximidade e o envolvimento com estes grupos foram decisivos no processo de investigação assumido e na própria escritura da pesquisa, pois permitiram a instalação de um exercício

\footnotetext{
${ }^{2} \mathrm{~A}$ referida tese de doutorado, intitulada "O corpo em movimento na capoeira", foi produzida no programa de pós-graduação da Escola de Educação Física e Esporte da USP, sob a orientação da profa. Dra. Yara Maria de Carvalho (ALVES, 2011).
} 
investigativo atento aos envolvimentos trilhados na relação entre pesquisador e capoeiristas. Para tanto, foi preciso aceitar o convite à vadiação.

\section{CONVITE À VADIAÇÃO}

Na vadiação o capoeirista se expõe aos domínios de outra temporalidade, diferente daquela mediada na ordem quantitativa e homogênea inscrita no compasso regular do tempo cronológico. Para Alvarez (2007, p. 21), o que move a constituição desta outra temporalidade não cronológica, é um perder tempo junto à tradição viva, algo possível através da vivência dos ritos, nas expressões estéticas, nos ritmos, na magia e na ética da mandinga, nos aspectos políticos de resistência e negociação com o adversário, na dimensão coletiva e em comunhão dos capoeiristas, na roda e no papel do Mestre de capoeira.

Pesquisador e capoeiristas entram na onda da vadiação quando se deixam contagiar pelo clima de brincadeira que ela instala. Tal contágio acossa quando pesquisador e capoeiristas sem veem provocados: a levada de um samba de roda pode provocar e a cadência pulsante do berimbau também. Os desafios do jogo corporal com o outro, a relação com o mestre, com o grupo, ou consigo mesmo, podem se apontados como estímulos que provocam, colocando pesquisador e capoeiristas em desassossego: o desejo pela capoeira alimenta este efeito de contágio e provocação, atando o exercício da vadiação à prática da existência.

Sob os domínios da vadiação, o tempo junto à capoeira se transforma em experiência de cultivo, na qual se inscreve o tempo dos acontecimentos, do qual só se tem acesso lá no momento mesmo em que o acontecimento se dá como evento, sendo impensável sua existência fora deste campo de implicação - espaço no qual os acontecimentos de fato se efetuam.

O cultivo da vadiação não é um exercício gratuito e fácil, que se dá a todo aquele que quer praticá-la. O cultivo possui uma dimensão carnal e laboriosa, sem a qual a capoeira não é posta 
literalmente em movimento. Desta forma, a capoeira não é para qualquer um, mas é para aquele que aceita conviver com a dureza, sem a qual não se entende a fundo esta prática. Para tanto, mestre Ananias alerta: "é preciso muito batente!" (Entrevista, 31/08/2009).

Imerso neste tempo contagiante e provocante, que se inscreve em meio ao cultivo da capoeira, o pesquisador catalisou a experiência vivida, aberto a uma disposição tateante e aventureira, que se deixou encharcar pela capoeira, para possibilitar o registro dos relatórios de campo - os diários e as entrevistas - como movimentos de uma visibilidade imersa no território estudado ${ }^{3}$.

\section{OLHAR QUE ESPRETTA NA HUMILDADE - VISIBILIDADE DO PESQUISA- DOR-CAPOEIRISTA}

Ao vadiar, o pesquisador-capoeirista se coloca numa atitude de espreita, na qual se abre à receptividade e ao acolhimento do inesperado, tateando o que lhe afeta no espaço onde se lança à vadiação. Assim, na espreita, o pesquisador-capoeirista se torna aprendiz, para tanto, basta, muitas vezes, só observar, como pontua contramestre Buda: "às vezes, só de observar as coisas que acontecem você já está aprendendo" (Entrevista, 31/10/2008).

O olhar que espreita simplesmente deixa vir tudo aquilo que lhe afeta, abrindo-se à receptividade das experiências vividas. Para Alvarez (2007, p. 145), esta receptividade própria da espreita concentra a atenção na direção dos eventos inesperados. Desta forma, ajustamos o olhar "ao tempo dos eventos, dos jogos, das conversas, dos encontros, das disputas. Sem pressa para realizar o que pretende, melhor ainda, sem muitas pretensões."

\footnotetext{
${ }^{3}$ Foram produzidos 30 diários de campo de novembro de 2008 a agosto de 2009. Através dos diários, as observações e frases captadas em meio à vadiação se transformaram em conhecimentos e descrições de modos de fazer. Foram realizadas oito entrevistas gravadas em áudio: quatro delas individuais, com mestres de capoeira (mestre Marcial - 01/11/2008; mestre Brasília - 02/12/2008; mestre Zequinha - 20/03/2009; mestre Plínio - 26/03/2009); uma com um professor (Rodrigo - Minhoca - 11/08/2009) e outra com um contramestre (Buda - 31/ 10/2008). Uma entrevista foi em dupla (mestre Gladson e professor Vinícius - 19/11/2008) e outra em grupo (entrevista com mestre Ananias e grupo - 31/08/2011). As entrevistas se constituíram como rodas de conversa, o que contribuiu para a instalação de um plano de experiência, onde se engendrou o discurso co-autoral entre pesquisador e sujeitos.
} 
Para tanto, é preciso humildade, pois, sendo humilde, o pesquisador-capoeirista se assume como aprendiz e, enquanto aprendiz se envolve e se deixa envolver no território no qual se implica, do contrário não aprende e não faz desta aprendizagem um exercício de pesquisa. Como efeito deste campo de envolvimentos o exercício investigativo abre mão do previsível, para mergulhar num campo de relações que o pesquisador não controla de antemão, pois não o forja sozinho, mas sempre na relação que estabelece com o território no qual se implica.

O princípio da cartografia, observado por Deleuze e Guattari (1995a, p. 22) ajudou a ajustar o olhar investigativo nestes termos. Segundo estes autores, a cartografia surge como um princípio "inteiramente voltado para uma experimentação ancorada no real." À luz deste princípio lançamos o desafio de pesquisar a capoeira assumindo uma visibilidade implicada junto a este território.

Para tanto, lançamo-nos à vadiação e aí encontramos a experiência da ginga.

\section{A GINGA COMO POTÊNCIA EMERSA NA VULNERABILIDADE}

Todos os movimentos da capoeira partem da ginga. Contramestre Buda assim afirma: "sem a ginga não tem como jogar capoeira" (Entrevista, 31/10/2008). Curiosamente, a fala de mestre Ananias amplia esta proposição: "nesta vida, pra você viver, tem que aprender a gingar, não é mesmo?" (Entrevista, 31/08/2009). A ginga como potência primeira, sem a qual os caminhos da vida - da capoeira - não são trilhados: eis aí a dimensão que interessa considerar sobre a ginga.

"Tem que aprender a ginga em primeiro lugar", diz mestre Ananias (Entrevista, 31/08/2009). A partir deste imperativo primeiro, a capoeira se inscreve nos músculos e nos modos de ser do sujeito que a toma para si.

O movimento que se engendra a partir da ginga é uma invenção sempre eventual forjada na relação entre dois oponentes no espaço 
do jogo de capoeira. Enquanto forma de regularidade, este movimento pode ser enquadrado em uma estrutura que o categoriza enquanto ataque, ou defesa, ou esquiva, ou negaça ${ }^{4}$. A partir deste enquadre verificam-se suas leis de construção formal, tornando regrada a experiência possível de movimento. Todavia, para além da regularidade dos movimentos possíveis, a experiência da ginga se disfarça, se desloca e se transveste infinitamente. Há algo de transgressor na ginga que contesta e subverte a própria ideia de ginga, revelando sempre outra coisa a cada vez que se repete na experiência de movimento. Não é "à toa" que todos os outros movimentos da capoeira derivam da experiência da ginga.

A ideia de ginga foge da ordem da representação, pois, quando em ato, é pura presença, e como tal, não se conforma a um modelo sem antes prescindir da consistência que a constitui, na virtualidade dos acontecimentos na qual ela se dá como evento.

Enquanto estímulo que convida o sujeito a se esgueirar na transgressão da ginga, podemos descrevê-la como um exercício lúdico de exploração das possibilidades de transferência do peso corporal. A mecânica da ginga descreve uma trajetória circular marcada por pontos divergentes e descentrados, através dos quais a dinâmica da transferência de peso se desloca.

Dito de outro modo, a ginga é um balanço que transita entre três pontos: dois adiante, paralelos, e um mais recuado, atrás entre os dois pontos paralelos. De um dos pontos à frente, o executor marca um passo e logo depois transfere o peso para a perna detrás. Deste último ponto, transfere novamente o peso para a frente e daí joga o passo para o lado, marcando a outra lateral - o terceiro ponto - de onde o ciclo se reinicia, demarcando, a cada passo, a transferência de peso.

As descrições acima forjaram uma estrutura lógica à ginga, a partir da qual se compreende o passo a passo de sua execução

\footnotetext{
${ }^{4}$ Negaça é um tipo de movimentação que visa desnortear o oponente, desestabilizando-o não tanto pela força física, pela agilidade ou condição física, mas pela malícia e astúcia do capoeirista frente às circunstâncias que o cercam (ALVAREZ, 2007, p. 183).
} 
motora - pelo menos no que diz respeito à ação das pernas dentro da mecânica geral do movimento. Nestes termos, a ginga não é, senão dentro desta estrutura formal descrita, o que a acomoda na ordem de um modelo, que funda a experiência possível desta habilidade.

Não haveria equívoco sobre o que é a ginga se não fosse o registro da experiência real que insiste numa transgressão furtiva atravessando os fundamentos da experiência possível. Observe-se a fala de mestre Marcial sobre certa ginga travessa que uma vez conheceu:

Conheci um mestre no Rio de Janeiro... não sei se ele ainda está vivo... [...] ele era um brancão assim, um baita de um alemão de idade avançada já... mas só a ginga dele já atrapalhava todo mundo... não era uma ginga esquematizada nem nada... miserável! Parecia que ia cair e não sei o quê que balançava tudo e atrapalhava todo mundo... era impressionante rapaz! (Entrevista, 01/11/2008).

A fala de Mestre Marcial ajuda a pensar que a ginga vai além da estrutura formal possível. Quando em ato, os pontos supostamente fixos na descrição lógico-didática se divergem, descentram-se e percorrem o espaço numa dinâmica que subverte esse suposto fundamento, disfarçando-o sempre a cada vez, segundo as relações em curso no exercício de exploração das possibilidades de transferência de peso. Cabe ao outro, oponente, se virar frente à diferença que o cerca e jogar com ela.

Todavia, uma injunção acossa: querem negar a todo custo o caráter transgressor da ginga. Não obstante, a transgressão sempre encontra seu próprio caminho, pois a ginga insiste em disfarçar-se, nem que seja um disfarce mais evidente na ginga da vida - voltando à fala de mestre Ananias exposta no início deste item - na qual o capoeirista joga com as possibilidades que lhe cabem, criando vida, mercado e consumo.

$\mathrm{O}$ veto à transgressão não está no movimento da ginga, mas nas propostas de trabalho corporal que reclamam pela experiência da ginga e pelos movimentos que dela se desencadeiam. Inscrevem- 
se nestas propostas duas práticas de cultivo: o treino como preparação física e o treino como convivência e cultivo na e da tradição.

\section{Para além dos rumos da esPortiVIzAÇÃo na CAPOEIRA}

Na capoeira Regional fala-se muito em treino. E dizem: "vamos treinar hoje?". Nestes termos o treino é um espaço de preparação, no qual se adquire um conhecimento sobre as habilidades motoras exploradas nesta prática. Trata-se, portanto, de um treino físico que lança mão de uma prática sistêmica e regular para elevar a performance motora à níveis mais avançados de funcionamento. Quanto maior domínio e refinamento na execução motora, mais eficiente seu caráter marcial e desportivo.

Ao longo do século XX a capoeira Regional comprou esta ideia, concentrando sua atenção por sobre a sedução inebriante do esporte e da marcialidade (SILVA, 2002). Todavia, perguntamos: o encontro com a capoeira Regional se resume ao treino físico? A fala dos mestres entrevistados reconhece a tendência a este resumo, mas, ao mesmo tempo amplia o espaço do treino, reportando-o para além dos rumos da esportivização. Assim argumenta mestre Marcial:

às vezes o capoeira treina muito [risos] o capoeira treina muito e esquece de sentar e conversar. O que falta pro capoeira é sentar e conversar sobre capoeira, conversar sobre a vida... pro capoeira falta viver este lado humano... estamos vendo os caras se tornando robô [...] Como o mestre Pastinha disse: "capoeira é tudo que a boca come". Tudo que você fala, tudo envolve a capoeira: a vida! (Entrevista, 01/11/2008).

Esta fala mobiliza-nos a pensar que a capoeira é muito mais do que uma atividade física e que, portanto, não se resume a um treino físico ostensivo. Algo ali, na prática, a torna um exercício da existência. A fala de professor Minhoca ajuda a compor este quadro ampliado sobre a experiência do treino. 
eu desenvolvi muito pouco treino na minha vida. [...] Eu vi que o treino, ele condiciona... [...] uma mente bem treinada é um ótimo escravo... o treino não combina com a capoeira, [...] porque toda vez que você treina você condiciona sua mente a responder sempre daquela maneira [...] Pra mim $[\ldots]$ o bom capoeira [...] é este que chega nos lugares da vadiação, no estágio da criança e este estágio não se treina, se brinca.... então o treino, hoje eu vejo mais como uma oportunidade de estar junto, de conviver... [...] O treino pra mim é o convívio, é a chance de poder encontrar estas pessoas, e aí o que eu vou fazer? O que é que eu digo? Tô vivendo!! Um dia depois do outro (Entrevista, 11/08/2009).

O treino, portanto, pode ser também espaço de convivência, no qual se instala o exercício do brincar, em detrimento de qualquer outro imperativo que não se corrompa frente às intensidades que este brincar institui.

O brincar desloca a relação entre mestre e aprendiz, já no treino físico, fatalmente se instala uma relação de oposição entre aquele que sabe (o mestre) e o ignorante que se imobiliza a espera do saber (o aprendiz). No convívio, ambos se colocam lado a lado e, juntos, se reconhecem enquanto companheiros que trilham a aprendizagem que há de vir nas relações que mobilizam.

Deleuze, em sua obra "Diferença e Repetição" (2006), lança uma ideia sobre aprendizagem que se aproxima muito deste exercício do aprender forjado na convivência e no companheirismo entre mestre e aprendiz. Assim pontua:

Nada aprendemos com aquele que nos diz: faça como eu. Nossos únicos mestres são aqueles que nos dizem 'faça comigo' e que, em vez de nos propor gestos a serem reproduzidos, sabem emitir signos a serem desenvolvidos no heterogêneo (DELEUZE, 2006, p. 48).

A partir da leitura de Deleuze (2006, p. 48-49), é possível entender a aprendizagem como um espaço de encontro com as potências que agem sobre as palavras e sobre os gestos - os signos 
- entrelaçando os sujeitos que se envolvem neste encontro até eleválos no plano dos movimentos reais, no qual só passam forças em relação.

O convívio é o espaço de encontro no qual mestre e aprendiz forjam o acesso a este plano dos movimentos reais: não é possível tangenciar este plano sem lançar-se à prática de um "aprender com" que coloca lado a lado mestre e aprendiz. Alvarez também registra, em seus estudos, as marcas deste "aprender com" na capoeira Angola. Assim demarca:

O mestre tenta colocar o aprendiz numa posição em que se aprende com e não como. Indicando de saída que o trabalho é muito mais ligado a uma disposição de composição do que de domínio técnico. Não se visa uma submissão ou domínio da técnica, mas um fazer com, compondo com os elementos envolvidos (ALVAREZ, 2007, p. 198).

O convívio sensibiliza o capoeirista a apreender tudo aquilo que o afeta quando se lança à relação que se permite tecer com o outro e com o espaço de encontro no qual se envolve. Desta forma, não há posições privilegiadas, tampouco papéis fixos que definem a relação de aprendizagem. $\mathrm{O}$ que existe são forças em relação que deixam em aberto uma necessidade de aprender com tudo, com todos e em qualquer lugar. A fala do professor Minhoca corrobora esta ideia:

no treino às vezes a gente brinca, as vezes fala sério, às vezes joga duro, às vezes treina umas coisas mais físicas, mas o grande lance, o grande aprendizado, pra mim está nas entrelinhas... (Entrevista, 11/08/2009).

Observe como a fala de professor Minhoca se aproxima das ideias de Deleuze (2006) sobre o "aprender com". Parece haver algo que liga profundamente as palavras do capoeirista às palavras do filósofo. O capoeirista pontua: "o grande aprendizado, pra mim, está nas entrelinhas [...]" e o filósofo lança a ideia: apreender é constituir espaços de encontro com aquilo que age sobre as palavras (DELEUZE, 2006, p. 48-49). 
Ao relacionar uma fala com a outra é possível pensar que algo se move nas entrelinhas. Este algo torna porosa toda e qualquer proposição firmada na relação entre mestre e aprendiz. É como se as proposições, isto é, os exercícios propostos no momento do treino, fossem palavras de ordem - usando aqui a expressão de Deleuze (1995b) - e a prática que a partir daí se desdobra seria o movimento das palavras de fuga, ou seja, as forças que rompem com o ciclo de obrigação implícito na proposição.

Professor Minhoca aposta neste movimento furtivo como exercício essencial sem o qual não aponta o desejo de "estar junto". Assim pontua: "e é engraçado, quanto menos exigência você faz mais o cara quer treinar. Você não precisa pedir pra ninguém vir treinar, eles vêm. Por quê? O ambiente é bom..." (Entrevista, 11/08/ 2009).

As diversas falas demarcadas neste item ajudaram a pensar que o treino não basta à formação do capoeirista, seja ele Angola ou Regional, pois a preparação física não é tudo. O movimento é tudo, mas ele pode ser expresso de múltiplas formas e é esta multiplicidade que provoca e instiga o capoeirista, contagiando não só o físico, mas também o ético e o estético na busca de um éthos, isto é, um modo de ser, que atrele a prática da capoeira ao exercício da existência.

Convém demarcar, no entanto, que não são todos os capoeiristas que alcançam esta profundidade que atrela a prática à existência. Muitos deles ficam pelo meio do caminho, atraídos pela aparência, pela visão espetacular dos movimentos físicos e assim deixam de tecer uma relação mais aprofundada com a capoeira.

\section{CERCO AO IMPREVISÍVEL NA CAPOEIRA REGIONAL}

O treino, enquanto preparação física, quer dar conta das situações de imprevisibilidade, de modo a reiterar a possível sustentação de um controle sobre a performance em meio ao jogo de capoeira. O registro do diário de campo a seguir ajuda a situar os domínios deste cerco à imprevisibilidade no espaço do treino. 
O mestre chega, chama o aluno mais graduado. Pede para iniciar o alongamento com todos. [...] Do alongamento, o mesmo aluno passa a monitorar o treino. Começa um aquecimento só com a ginga. De longe o mestre observa... analisa cada um de seus alunos com atenção e cuidado. Num ímpeto, movese em nossa direção. Aborda um ou outro. Ele tem sempre algo a dizer, seja no movimento complexo ou no mais elementar. Em sua fala, chama-nos à consciência do exercício. Depois de um afetuoso meio-abraço, parte para outro aluno e assim, de aluno em aluno, percorre a todos com o mesmo cuidado e atenção.

Da ginga se desdobram algumas sequências elementares (ginga e negativa; ginga, negativa e rolê; ginga e meia-lua; ginga e queixada; ginga e armada; $\mathrm{e}$ por aí vai...). A ideia é trabalhar possibilidades de movimento na relação elementar entre corpo e espaço.

O mestre intervém. Parece se adiantar na correção de meu pensamento e argumenta [...] Todos olham o mestre fixamente; cerram o olhar num claro esforço para assimilar tudo que escutam atentamente. Entre o esforço do entendimento e o encantamento daquele irromper de palavras, o corpo imóvel parece estar assimilando: armando sua estratégia para alcançar tudo aquilo que ouviu pela boca do mestre.

[...] a fala é preciosa nos treinos [...]. É pelo discurso verbal que o mestre investe para chamar o aprendiz à consciência de seu esforço [...]. O aprendiz escuta, o corpo absorve, a prática experimenta... acomoda, reacomoda e, neste liame contínuo e dinâmico, movese o aprendiz a um maior domínio de seu esforço (Diário n. 05, São Paulo, 26 Nov. 2008).

Analisemos mais detidamente a situação registrada no fragmento de diário acima: mobilizamo-nos à prática de certa habilidade; lá, no momento mesmo em que a repetição é movimento, experimentamos forças puras, traçados dinâmicos no espaço. Num dado momento, o mestre nos chama à consciência; paramos; fixamos o olhar atento sobre ele; o corpo se imobiliza; assimila. Nesta 
imobilização a consciência é chamada à pauta; forma-se então um ponto fixo, sobre o qual se ajeita um Eu que contempla, imbuído da tarefa de avaliar e medir "à quantas anda" o hábito, o comportamento. Neste momento, imóvel, um registro cognitivo é forjado, permitindo a atualização do hábito. Assim, entre um fôlego e outro da repetição, o comportamento registra automatizações que dão testemunho de um domínio em processo de aquisição.

Cada chamada à consciência do mestre implica na edificação de um ponto sobre o qual a consciência se ajeita. Assim, de um ponto a outro, na sucessão do treino, o canal da razão suficiente é re-sintonizado, o que mantêm o treino sempre afinado com os movimentos da recognição.

Segundo Kastrup (2004), a aprendizagem como recognição torna possível a conscientização do itinerário que leva de um estágio inicial de aprendizagem à aquisição de hábitos que são requisitados e aplicados como soluções que querem dar conta dos problemas postos. Quanto mais automática a requisição e aplicação destes hábitos, mais eficiente a solução dos problemas.

Segundo Alvarez (2007, p. 103), o hábito, na recognição, reduz a aprendizagem ao treino sistemático de respostas ou ações gerais que operam um reforço dos modelos e esquemas motores assimilados. Desta forma, o hábito aponta para um "aprender como", sustentado sob os domínios da recognição.

Para Deleuze (2006, p. 27), no hábito, "só agimos com a condição de que haja em nós um pequeno Eu que contempla." Este "Eu que contempla" é o agente que impõe a recognição. Todavia, entre os pontos que sustentam a edificação deste hábito corre a repetição que não se deixa capturar pelo hábito, justamente porque não compreende em si a contemplação, mas antes, o movimento. Assim, enquanto movimento, a repetição:

implica uma pluralidade de centros, uma superposição de perspectivas, uma imbricação de pontos de vista, uma coexistência de momentos que deformam essencialmente a representação (DELEUZE, 2006, p. 93). 
É por isto que a repetição sempre aponta para a possibilidade da transgressão, pois ela é da ordem do movimento e, enquanto tal, sempre se desloca, se aperfeiçoa, se disfarça.

O capoeirista Regional encontra caminhos que o desviam do cerco à imprevisibilidade quando enxerga a constituição dos hábitos em suas entrelinhas, onde corre, o movimento e as potências de transgressão que eles suportam. A fala de mestre Marcial ajuda a compor esta ideia:

tem as sequências de movimentos do mestre Bimba, tem as sequências que às vezes passo pro pessoal [...] e isto é legal como forma de treinamento, pra pessoa poder memorizar e desenvolver seu jogo, mas, às vezes isto ia ficando meio automático, então percebi a necessidade de fazer mais livre mesmo [...] deixei de determinar a sequência [...] Hoje eu me preocupo em fazer a cada dia uma coisa diferente [...] Enfim, preferi dá um pouquinho mais de liberdade da pessoa crescer dentro da capoeira e vivenciar mais, né, sem perder a tradição nem nada, né... (Entrevista, 01/11/2008).

A prática de ensino da capoeira foi ensinando o mestre sobre a necessidade de ir além das sequências de movimento que visam à assimilação e ao reforço de esquemas motores prévios. O mestre não deixa de registrar a importância deste momento, em que a recognição estende seus domínios na busca pela automatização dos movimentos, mas também alerta para a necessidade de certo relaxamento sobre esta tendência à automatização.

A fala do Mestre inspira pensar que a vivência é o meio a partir do qual o capoeirista pode experimentar este escape à recognição, pois ao vivenciar, o capoeirista não se dedica apenas à ordem disciplinar imposta no treino físico, mas também se depara com a vadiação, o aprendizado da dissimulação, da malícia, o momento ritual do jogo, no qual experimenta a possibilidade de expansão dos sentidos, liberando-se do controle consciente sobre a performance sensório-motora. Assim, ao alimentar o desejo por esta vivência intensa, o capoeirista Regional também se vê às voltas com 
o imprevisível, o que orienta seu olhar prospectivo e aventureiro e aprofunda suas relações com esta prática.

\section{ENCONTRO COM O IMPREVISÍVEL NA CAPOEIRA ANGOLA: A DANÇA DA MORTE}

Na capoeira Angola não há espaços para a recognição, pois, muito maior que ela, se inscreve um exercício de cultivo na e da tradição. Ao aceitar o convívio como campo intensivo de aprendizado da tradição da capoeira, o angoleiro ${ }^{5}$ é atraído pelo intempestivo, pelo jogo porvir. O imprevisível é como um amante irresistível na Angola, pois instiga à roda.

Certa vez, numa conversa com mestre Ananias escutei a seguinte frase: "a capoeira é a dança da morte". Esta frase sacudiu meus pensamentos por longos dias. Impossível se deparar face às profundidades descobertas por este aforismo, sem se perceber defronte ao abismo que ele descerra. O abismo é arrebatador. É cruel. Frente a ele, há somente duas alternativas: se virar pra dar conta do arrebatamento que transborda, esgueirando-se nas tramas do imprevisível, ou contemplar, quase catatônico e aterrado, uma experiência que, de tão intensa, engole a pequenez do Eu que contempla. No primeiro caso, ousamos aceitar o desafio. No segundo, somos impedidos, por uma recognição que trava frente à incapacidade de controle do imprevisível. Neste último caso, alguns diriam: falta treino; outros reiteram: falta cultivo e disposição ao imprevisível. Seja como for, algo sempre falta, apontando para uma possível reação porvir, a um passo à frente da experiência vivida.

Encontramos indícios de um aprendizado atento à irredutibilidade do imprevisível na fala dos mestres. Quando perguntado sobre seu processo de aprendizado da capoeira, mestre Zequinha assim se expressou:

o mestre fazia a gente treinar sozinho, e treinar, e treinar, e depois perguntava pra gente: "tá fazendo o movimento direitinho?" Se tá direitinho ele já

\footnotetext{
${ }^{5}$ Termo usado para designar o agente da capoeira Angola.
} 
colocava a gente pra treinar junto e dizia pra um: "Chuta lá", e o outro tinha que se virar pra se defender... [...] o mestre nunca ensinava a gente a se defender dizendo, por exemplo: "Faz aí uma negativa, uma esquiva aí..." Não tinha isto! Era só ataque e... se vira aí... Então a gente tinha que se virar... (Entrevista, 20/03/2009).

Observe a frequência com que a expressão "se vira" aparece neste curto fragmento. Ter que "se virar" é um imperativo sem o qual não há jogo, mas aplicação de gestos automatizados. Enquanto imperativo mobilizado na relação, o "se virar" só existe no espaço e tempo dinâmico onde este imperativo aponta. A fala de mestre Plínio ajuda a sustentar esta ideia. Quando perguntado sobre seu processo de aprendizado da capoeira, assim pontuou:

eu me recordo do primeiro treino que tive com o mestre Gato... ele me deu uma "meia-lua-de-frente", aí eu desci, mas o golpe me acertou, embora eu tenha me esquivado. No segundo movimento, o mestre fez a mesma coisa e eu já saí melhor... ele não me passou nenhuma defesa, ele queria exatamente, que eu reagisse... e hoje eu acredito que, muitas vezes, o que falta é a gente ensinar o aluno a reagir de forma mais espontânea. A gente prefere dizer pro aluno que a negativa, por exemplo, é isto, e isto e aquilo... e desfia pra ele uma série de normas e regras pra fazer este e aquele movimento. Então, os mestres antigos, os primeiros capoeiristas, os mestres destes mestres que estão aí, eles não tinham esta metodologia de aula, o negócio é muito mais na prática, é tacar o pé e ver como você vai se sair... (Entrevista, 26/03/2009).

O fragmento acima registra as impressões de um aprendizado movido pela transgressão do "se virar". Ao forçar o aprendiz "a reagir de forma mais espontânea", o mestre alerta sobre a face dura e cruel do jogo, chamando a atenção para as imprevisibilidades irredutíveis ao espaço do jogo com o outro. A reação ao "se virar" forja o "pulo do gato". 
Segundo mestre Zequinha:

O "pulo do gato" você não ensina, você cria na hora, não é uma coisa que se ensina... então, você treinou sempre aquela esquiva naquele golpe, mas quando você tá lá na contramão e pensa: "o que vou fazer?" não tem como! Dá um salto pra trás, meio de lado e aquilo ali é o "pulo do gato", você criou na hora ali e tá feito... (Entrevista, 20/03/2009).

Convém demarcar que a fala de mestre Zequinha não é só dele, aliás, a humildade - e por que não dizer, a disposição de um conhecimento engendrado no plano coletivo, - impede de lhe dar a autoria desta fala. Ele próprio a credita ao mestre João Pequeno, sua referência maior na capoeira. Ao desempenhar com suas próprias palavras a fala de seu grande mestre, Zequinha comunga com ele, fazendo estas palavras ecoarem em um plano coletivo, no qual a tradição da capoeira Angola é posta à disposição de todos que dela se servem ${ }^{6}$.

Voltando ao "se virar", é possível perceber que este imperativo também atravessa a fala de mestre Zequinha, forçando-o a desempenhar, no curso de uma fala, o ensinamento de seu preceptor. Fica evidente a potência de um ensinamento que contagia não só as ações do capoeirista, mas também a sua forma de pensar e dizer.

Todavia, a prática da capoeira no ambiente das academias de ginástica insiste em tolher esta potência que move o "se virar". Tal situação é polêmica, pois envolve um processo de depuração e domesticação da prática da capoeira. Neste processo, o ensino da capoeira foi se constituindo enquanto prática pedagógica que, atrelada aos discursos velados do politicamente correto e do didaticamente seguro, levou a um quase impedimento deste "se virar" nos métodos de ensino. Como resultado, a tradição da capoeira se viu enquadrada por uma pedagogia que tomou para si a responsabilidade do ensino, ao constituir um método sistemático que reduz a aprendizagem à assimilação do passo a passo da execução motora.

${ }^{6} \mathrm{~A}$ fala mítica dos grandes mestres do passado possui um caráter transgressor que move o capoeirista a servir-se dela para mobilizar a tradição potencialmente inscrita no curso desta fala.

Movimento, Porto Alegre, v. 19, n. 02, p. 277-300, abr/jun de 2013. 
Desta forma, o ensino da capoeira ganha respaldo didático e pedagógico, o que favorece o assegurar da sanidade física do aprendiz. Todavia, frente à eminência deste enquadre instalado por uma aprendizagem sistêmica e ordinal - que pode ser designada "aprender como" - a transgressão acossa. O capoeirista se esquiva das restrições de uma pedagogia castradora quando enxerga não uma, mas infinitas saídas, ou seja, quando se deixa levar pelo imperativo do "se virar"7.

\section{A REPETIÇÃO COMO FORÇA DESVIANTE - FLERTAR COM O IMPREVISÍVEL}

Para mestre Plínio, só a repetição ensina o capoeirista a jogar com o "se virar". Assim demarca: "é com a repetição que seu corpo aprende a se desenrolar literalmente assim: a se virar." (Entrevista, 26/03/2009). Nestes termos, o capoeirista só consegue lidar com este "se virar", sempre episódico e eventual, quando insiste na repetição.

Segundo Deleuze (2006), a repetição corre numa via de mão dupla, onde se inscrevem duas ordens irredutíveis: de um lado a ordem do intensivo, do outro a ordem do regular. O intensivo aponta para a possibilidade de transgressão e deslocamento daquilo que se repete. Já o movimento regular, não se refere exatamente à repetição, pois esta é sempre intensiva, mas à sua disposição ordinal que torna possível a organização e evolução sistemática de certo comportamento em edificação no processo da repetição.

O capoeirista é mobilizado a repetir o imperativo do "se virar", justamente porque frente às demandas porvir deste imperativo, uma possibilidade outra acossa, colocando à prova as regularidades já assimiladas na repetição.

\footnotetext{
${ }^{7} \mathrm{O}$ artigo de Palma e Felipe (1999), intitulado "A experiência da capoeira e a pobreza da Educação Física: uma reflexão sobre as práticas de atividade física" acrescenta a esta discussão. Embora apresentando um referencial teórico e conceitual distinto daquele aqui trabalhado, as reflexões reiteram sobre a precariedade de uma educação que aliena a experiência, moldando-a segundo a fixação dos hábitos. A experiência com a capoeira, no entanto, ainda consegue se esquivar desta precariedade quando insiste em manter sua força originária e o cultivo da tradição. Ao que parece, o imperativo do "se virar", aqui observado, apresenta uma via potente que enriquece a experiência com a capoeira, garantindo seu poder de esquiva em suas práticas na contemporaneidade.
} 
Tais regularidades assimiladas possuem de início uma função de referência, a partir da qual dispara a força desviante da repetição (PASSOS; KASTRUP, V.; ESCÓSSIA, 2009, p. 76-91). O movimento daquilo que assume a função de referência corre sob as regularidades, abrindo caminho para seu deslocamento.

A ideia da aprendizagem da capoeira, a partir de habilidades adquiridas, ajuda a compor esta ideia. Os esquemas motores memorizados através da repetição de sequências de ataque e defesa funcionam como referência no jogo da capoeira. Tais esquemas podem ser requisitados pelo capoeirista no momento do jogo, como recurso suposto à resolução de certa situação em ato. Todavia, as demandas situacionais do jogo exigem desvios, muitas vezes insuportáveis à aplicação ordinal destes esquemas.

$\mathrm{O}$ jogo de capoeira deve se abrir aos efeitos desencadeados na relação estabelecida entre os jogadores, do contrário, não há diálogo, mas jogo combinado. No diálogo, o jogo com o outro se abre aos desvios do movimento, fazendo reverberar a função de referência dos esquemas motores até os seus limites, impelindo-os à diferenciação. Frente à eminência do jogo com o outro, a aplicação dos esquemas motores memorizados precisa "se virar".

Aquilo que está porvir no "se virar" sempre estará um passo à frente das possibilidades reais e proximais já acomodadas. É como se, frente ao abismo de um porvir incerto, a rememoração vacilasse e, por um instante, abrisse espaços à invenção do que há de vir, onde a memória inventiva se instala furtiva ${ }^{8}$.

Todavia, é preciso estar na espreita dos acontecimentos, como diria Alvarez (2007) e, para tanto, a atenção se dirige ao outro, oponente. A presença do outro e a impossibilidade de controlar o exato movimento que há de vir desta presença alheia à frente, forçam a atuação da memória inventiva, sem a qual não se dá curso às demandas do "se virar".

\footnotetext{
${ }^{8}$ Segundo Deleuze (2006, p. 396), a rememoração é o campo da memória onde as regularidades estendem seus domínios, pois só opera com "termos e lugares fixos". A repetição que a rememoração engendra revela estágios de desenvolvimento de certo comportamento. Por outro lado, na memória inventiva, a repetição "só pode ser mascarada por acréscimo e posteriormente", desta forma, a repetição, não é, mas está sempre porvir.
} 
Segundo Deleuze (2006), a repetição, sob os domínios da memória inventiva, comporta uma força desviante que a impele à diferenciação daquilo que se repete. Tal força desviante é transgressora, pois desloca os hábitos - as regularidades que evoluem progressivamente na repetição - dando-lhe novas formas, deslocando-os para outros lugares, provocando novos agenciamentos e produzindo novas conexões. Desta forma, os hábitos não levam a um automatismo restrito, que fixa a repetição numa forma devida, mas permitem um acesso engajado à experiência desafiadora do "se virar".

O hábito que se inscreve na experiência do "se virar", introduz a mudança e a variação, pois aponta para a imprevisibilidade do que há de vir. Desta forma, tal como salienta Alvarez (2007), o hábito se inscreve enquanto um processo de transformação das sensibilidades e das condutas, segundo o jogo que o capoeirista traça com ele próprio e com o território no qual se implica.

\section{ENFIM...}

A experiência investigativa imersa em meio a tempo da vadiação mostrou que para além das dicotomias, que demarcam as distinções entre capoeira Angola e Regional, evidenciam-se as práticas que movem o capoeirista no cultivo da e na tradição. Tais práticas, em última análise, apontam para o brincar como experiência inerente ao exercício da vadiação. O cultivo deste brincar cresce com o auscultar de uma vontade de aprender, que chama a atenção do sujeito para ocupar-se consigo junto à prática que o instiga. Deste referencial irredutível - o corpo que se ocupa consigo - o sujeito se lança à relação com o mestre e com o grupo, e assim, coletivamente, a capoeira surge como movimento e, enquanto tal, coloca o capoeirista face aos desafios que atravessam os relacionamentos, alertando-o sobre a necessidade de "se virar".

A ginga desperta no aprendiz esta necessidade. A preparação física e técnica tentam controlá-la, mas a experiência de movimento - no jogo corporal com o outro - e a convivência alertam sobre sua 
natureza transgressora. Ao se ocupar com estas transgressões, vadiando, o aprendiz se envolve e é envolvido pela capoeira e, em meio a estes envolvimentos, o capoeirista a toma para si como prática de sua existência: como arte/técnica de seu viver. 
The meeting with the capoeira at the time of vagrancy

Abstract: This article is a part of doctoral thesis which investigated the practices of constitution/invention of the capoeirista (the capoeira player). We have researched groups of capoeira Angola and Regional, in São Paulo, Piracicaba, Botucatu and Jaú. The principles of cartography (DELEUZE; GUATTARI, 1995a) have mobilized this investigation, making possible the constitution of the dailies and recorded interviews, as movements produced between researcher and individuals. The research writing has gotten deep in the relations and singularities discovered in these movements to forge the analytical exercise, understanding it as multiplicity. We have observed that in the time of vagrancy, the capoeira pops us as movement through the practice of swing. From this practice growing the training, in Capoeira Regional and the living together, in Capoeira Angola. These practices although differents, require a certain disposition to unexpectable, without which it have not installed the playing experience - the vagrancy - neither the capoeirista desire to take on the capoeira as the practice of his existence.

Keywords: capoeira. learning. art of living.

\section{El encuentro con la capoeira en el tiempo de la vagancia}

Resumen: El artículo es parte de una tesis doctoral que ha investigado las prácticas de la constitución/ invención de lo capoeirista. Seguimos grupos de Capoeira Angola y Regional en São Paulo, Piracicaba, Botucatu y Jau. El principio de la cartografía (DELEUZE, GUATTARI, 1995a) movilizó a la investigación, permitiendo la formación de los diarios y las entrevistas, como movimientos producidos entre el investigador y el sujeto. La escritura la investigación ha utilizado las relaciones y singularidades descubiertas en estos movimientos para forjar el ejercicio analítico, entendiéndolo como multiplicidad. Se observa que en medio del tiempo de la vagancia, la capoeira emerge como movimiento a partir del cultivo de la "ginga". Desta cultura surge el entrenamiento, en la Capoeira Regional, y la convivencia, en la Capoeira Angola. Estas prácticas de cultivo, aunque sean distintas, requieren una cierta disposición a imprevisibilidad, sin la cual no se asienta la experiencia de jugar - la vagancia - ni mismo el deseo de tomar la capoeira como practica del su existencia.

Palabras clave: capoeira. aprendizaje. arte de vivir. 


\section{REFERÊNCIAS}

ALVAREZ, J. M. O aprendizado da capoeira angola como cultivo na e da tradição. Tese (Doutorado) - Universidade Federal do Rio de janeiro, Rio de Janeiro, 2007. Disponível em: <http://www.dominiopublico.gov.br/pesquisa/ DetalheObraForm.do?select_action=\&co_obra=132342>. Acesso em: 23 mar. 2013.

ALVES, F. S. Uma conquista poética na dança contemporânea: capoeira aplicada a composição coreográfica. Revista Motriz. Rio Claro: depto. Educação Física/ Unesp; Vol. 9; n. 3.; set/dez 2003.

Face a ecaF: quando Tu dança. Campinas. Dissertação de Mestrado: IA UNICAMP, 2006. Disponível em: <http://www.bibliotecadigital.unicamp.br/document/ ?code=vtls000402989>. Acesso em: 23 mar. 2013.

O corpo em movimento na capoeira. Tese (Doutorado) - Escola de Educação Física e Esporte - USP, 2011. Disponível em: <http://www.teses.usp.br/ teses/disponiveis/39/39133/tde-30012012-150556/pt-br.php>. Acesso em: 23 mar. 2013.

DELEUZE, G. Diferença e repetição. 2. ed. Rio de Janeiro: Graal, 2006.

DELEUZE, G.; GUATTARI, Félix. Mil Platôs: capitalismo e esquizofrenia. São Paulo: Ed. 34, 1995a. v. 1.

Mil Platôs: capitalismo e esquizofrenia. São Paulo: Ed. 34, 1995b. v. 2.

FALCÃO, J. L. C. O jogo da capoeira em jogo e a construção de uma práxis capoeirana. Tese (Doutorado) - Universidade Federal da Bahia, Salvador, 2004.

FOUCAULT, M. A ordem do discurso. São Paulo: Loyola, 1996.

KASTRUP, V. A aprendizagem da atenção na cognição inventiva. Psicologia \& Sociedade, Porto Alegre, v. 16, n. 3, p. 7-16, 2004. Disponível em: <http:// www.scielo.br/scielo.php?script=sci_arttext\&pid=s 0102 $71822004000300002 \&$ lng=en\&nrm=iso>. Acesso em: 23 mar. 2013.

KASTRUP, V.; TEDESCO, S.; PASSOS, E. Políticas de cognição. Porto Alegre: Sulina, 2008.

NIETZSCHE, F. A vontade de poder. Rio de Janeiro: Contraponto, 2008.

PALMA, A.; FELIPE, J. A experiência da capoeira e a pobreza da educação física: uma reflexão sobre as práticas de atividade física. Movimento, Porto Alegre, v. 5, n. 10 , p. 51-57, out. 1999.

PASSOS, E.; KASTRUP, V.; ESCÓSSIA, L. (Org.). Pistas do método da cartografia: pesquisa-intervenção e produção de subjetividade. Porto Alegre: Sulina, 2009. 
SILVA, P. C. C. A Educação Física na roda de capoeira... entre a tradição e a globalização. Dissertação (Mestrado) - Universidade de Campinas, Campinas, 2002. Disponível em: <http://www.bibliotecadigital.unicamp.br/document/ ?code=vtls000279885>. Acesso em: 23 mar. 2013.

Endereço para correspondência:

Flávio Soares Alves

Rua Itavuru, 145 - Planalto Paulista - São Paulo - capital.

CEP: 04069-020

Recebido em: 09.07.2012

Aprovado em: 24.02.2013 